\title{
THE RISE OF SCIENCE IN RUSSIA
}

\section{By Eng.-Captain Edgar C. Smith, O.B.E., R.N.}

$\mathrm{I}^{\mathrm{N}}$ N 1698, on February 6 and again on March 8, Peter the Great visited Greenwich Observatory, and as Flamsteed recorded, made observations of Venus. In Holland he had studied astronomy and other. sciences, he had inspected Leeuwenhoek's microscopes and Ruysch's anatomical collections, and thus while pursuing his main object of learning shipbuilding and recruiting instructors and artisans, both in Holland and England he made himself acquainted with some of the science of the day. He was then about twenty-six years of age. Twenty years later he again visited Holland, but this time went on to Paris where he inspected the Arsenal, tapestry and printing works and natural history collections, went to the Sorbonne and Observatory and attended a meeting of the Royal Academy of Sciences, where he talked of maps. The newly founded city of St. Petersburg had already become his seat of government, in preference to Moscow, and one of his cherished ambitions was to establish in it an academy after the fashion of the Paris and Berlin Academies of Sciences and the Royal Society of London.

This scheme, however, Peter did not live to carry through, and it fell to his widow and successor, Catherine I, to inaugurate the Imperial Academy of Sciences, which for two hundred years was the scientific centre of the Russian Empire. The Academy was established in 1725, and it was at the last ordinary meeting of the Royal Society presided over by Newton that a letter from the Academy was read giving an account of its inauguration. Though the City and the Academy have changed their names (and the latter its location) they both are monuments to Peter the Great, who was the first to open the hitherto closed portals of his Empire to scientific thought and knowledge.

It is perhaps unnecessary to dwell on the backward state of Russia in the seventeenth century. Though the Empire stretched from the Baltic to the Pacific, from the Arctic to the Caspian, there were few schools and no universities. Russia can lay no claim to a Copernicus, Kepler or Galileo ; and the older histories of science can be searched in vain for the names of Russian contributors to natural knowledge. When the Academy of Sciences was in the making it was therefore necessary to draw its members from other lands, and so from France came its first astronomers, from Switzerland its first mathematicians and from
Germany its first naturalists, and right throughout the eighteenth century, not only men of science, but also others learned in history, languages or architecture or skilled in painting, mechanics or engineering, were recruited from western countries by succeeding sovereigns. All these men were made members of the Academy of Sciences, provided with comfortable homes and adequate pensions, and St. Petersburg was the main centre of their activities.

Among the earliest to arrive in St. Petersburg were the French astronomer Joseph Delisle (1688-1768) and his brother Louis Delisle de la Croyère, and the Swiss mathematicians, Nicolas Bernoulli (1695-1726), his famous brother Daniel Bernoulli (1700-82) and James Hermann (16781733). Then in 1727 came Leonard Euler. He was then only twenty years of age, but he was destined to shed more lustre on mathematical science in Russia than any other individual. It is said that about half the memoirs in the Transactions of the Academy came from his pen. Joseph Delisle remained in Russia for twenty-one years establishing an observatory and lecturing to many students. His brother Louis Delisle de la Croyère served the State in various ways and perished with Behring on Behring Island in 1741. Nicolas Bernoulli died in St. Petersburg about a year after his arrival there, Daniel returned to Basle in 1733 while Hermann's stay was of the shortest. Three other men of science who were attracted to St. Petersburg in these early days were T. S. Bayer (1694-1738), who was given a chair of Greek and Roman antiquities, J. G. Gmelin (1709-55),professor of chemistry and natural history, and G. F. Muller (1705-83), who taught Latin, geography and history. The services of Muller led to his being called the "great father of Russian history".

One of the urgent needs of the Russian Government was a better knowledge of the many lands and races under its jurisdiction. Peter the Great had felt this need and for a number of years employed the German physician and naturalist Daniel Messerschmidt (1685-1735) to travel in Europe and Asia. On his journeys in Siberia Messerschmidt had the companionship of one of the many Swedish prisoners of war Peter had sent there. In the reign of the Empress Anne quite a large expedition was sent to explore Siberia from the Urals to the Pacific. Behring, the Danish 
navigator, Delisle de la Croyère, Gmelin and Muller were among the leaders of this expedition which left St. Petersburg in 1733 and did not return until 1743. Others who afterwards took part in the expedition were the Russian botanist S. Krascheninnikof (1712-54), the German medical man and naturalist G. W. Steller (1709-45) and the German savant J. E. Fischer (1697-1771), who became professor of antiquities at St. Petersburg.

For ten years Gmelin, Muller and their fellows explored the plains and mountains of Siberia from Tobolsk to Okhotsk, sailed on the great rivers $\mathrm{Ob}$, Yenisei and Lena, searched for the remains of the great animals from which fossil ivory had long been obtained, and gathered together a great mass of information on this vast and sparsely populated land. Behring and many of his companions died in 1741 in the Far East, and Steller after being wrecked and suffering years of hardship regained touch with the home authorities only to disappear for ever. Great results were achieved by the expedition and it paved the way for that of Pallas referred to in NATURE of September 20, p. 334 .

In the years which separated these two expeditions considerable strides were made in the furtherance of science in the capital. The reign of Catherine had been followed by those of Anne and Elizabeth, and in 1762 the great Catherine II ascended the throne. The University of St. Petersburg was founded in 1747 ; that of Moscow in 1755. Perhaps the most notable figure in St. Petersburg at this time was Michael Lomonosof (1711-65), father of modern Russian literature. Educated partly at the Academy, he had studied chemistry, mineralogy and metallurgy in Germany. In $1745, \mathrm{G}$. W. Richmann was made professor of experimental philosophy; in 1747, Muller was made historiographer to the Russian Empire, and in 1751, A. N. Grischow (1726-60) became professor of astronomy and secretary to the Academy. In 1753, the year Franklin received the Copley Medal of the Royal Society, Richmann was killed by lightning when repeating some of Franklin's experiments. In 1757 the scientific coterie was joined by Apinus, who two years later at St. Petersburg published his "Tentamen Theoriæ Electricitatis et Magnetismi", one of the great works on electricity in the eighteenth century. In 1760 Rumoffski published his "Course of Mathematics", said to be the first printed in the Russian language. Rumoffski had studied under Euler in Berlin and he was well known as a mathematician, astronomer, geographer, traveller and teacher. When more than seventy years of age he was curator of the University of Kazan.

With the accession of Catherine II in 1762 a new era in Russian education, science and literature began. Of German parentage, even her marriage to a boorish prince and her long acquaintance with the intrigues and boredom of the Russian Court could not destroy her love of books. She was fond, too, of patronizing learned men. She was able, in 1766, to prevail upon Euler to return to St. Petersburg from Berlin; she entertained Diderot like a prince; she asked D'Alembert to become the royal tutor and she sent her portrait to the Irish chemist and mineralogist Kirwan. Soon after Euler returned to St. Petersburg, he was joined by the Swedish astronomer, Lexell, and by Nicolas Fuss (1755-1825). These proved great friends to Euler in his blindness. In 1776 the Academy of Sciences celebrated its jubilee and in Weld's "History" will be found the letter of Euler's son, J. A. Euler, announcing that the Academy had elected the president of the Royal Society, Sir John Pringle, a foreign associate. Euler's death in 1783 left a blank in the Russian mathematical world never filled. He had thirteen children and of these Jean Albert (1734-1800), was the professor of natural philosophy, Charles (d. 1790), was a doctor at the Russian court and Christopher (d. 1814) rose to be a major-general in the Russian Army. His son-in-law Nicolas Fuss, in 1800, became secretary of the Academy of Sciences, in which post he was succeeded by his son Paul Henry. Another son, George Albert Fuss, was one of the first assistants at Pulkowa Observatory.

Towards the end of the reign of Catherine (who died in 1796), and during the reigns of Paul and Alexander I, scientific work seems to have languished somewhat. No doubt this was partly due to the disturbed state of Europe during the French Revolution and the Napoleonic regime. After this period of comparative stagnation science took on fresh activities during the whole thirty years reign of Nicolas I, who ascended the throne in 1825. Though a monarch who declared that "Despotism is the essence of my government, and it suits the genius of the land", yet he was not averse to giving his blessing to scientific projects and showering gifts on men of science. On one occasion he sent a diamond ring to James Nasmyth, the engineer; on another he presented a fine china vase to Snow Harris, the electrician, and when Airy, the Astronomer Royal, was refused permission by the British Foreign Office to accept a Russian knighthood, Nicolas had a gold medal especially struck for him.

Soon after Nicolas came to the throne the Academy of Sciences put forward a plan for a new central observatory. Nicolas, through his minister, replied in 1830 "that the honour of the country appeared to him to demand the establishment, near the capital, of a new astronomical observatory, 
conformable to the actual state of Science, and capable of contributing to its ulterior advancement". In 1835 the foundation stone of the great Pulkowa Observatory was laid and in 1839 the institution was completed at a cost of about $£ 100,000$. It stands about ten miles south-east of Leningrad and unfortunately is now in the defensive zone of that city. Directed from 1839 until 1890 , with but a brief break, by the Struves, father and son, it became a Mecca for astronomers, and Gould, the American astronomer, once called it "the astronomical capital of the world". The Struves had many able assistants and they were visited by eminent astronomers from all over the world. Russia was also greatly indebted to the Struves for their geodetical work which included the measurement of an are of the meridian from the north of Scandinavia to the River Danube. When Otto Struve retired he was succeeded by Theodor Bredikhine (1831-1904) who previously had been professor of astronomy at Moscow, and he in turn was succeeded by Johan Backlund (1846-1916), who though Swedish by birth became a naturalized Russian.

The Government of Nicolas also did much to further magnetic and tidal observations and geographical and geological excursions. In 1828, Hansteen, the Norwegian physicist, accompanied by the German physicist, G. A. Erman, travelled to Siberia making magnetic observations, and their journey was followed by that of the great Humboldt who was accompanied by Ehrenberg and Gustav Rose, the chemist and mineralogist. It was Humboldt who put forward the plan for a world magnetic survey in which Great Britain and Russia took the leading part. Another expedition of note was that made in 1841-45 by Murchison, the French geologist de Verneuil and the Russian mineralogist N. I. Koksharov (1818-93), who, in 1865 , became director of the Imperial Mineralogical Society of St. Petersburg. Two other eminent Russian geologists of this time were Gregor von Helmersen (1803-85), who, in 1841, published a geological map of Russia, and K. E. von Eichwald (1795-1876), professor of palæontology at St. Petersburg. The greatest naturalist of the reign of Nicolas in Russia, however, was the German, Karl E. von Baer (1792-1876), to whom the Royal Society in 1867 awarded the Copley Medal; this being the first time the medal had gone to Russia. Since von Baer's time it has been awarded to Metchnikoff, Mendeléeff and Pavlov.

It may be presumed that during the eighteenth century German and Swedish works on chemistry, mining and metallurgy found their way into the mining districts of European Russia and Siberia, but chemistry does not appear to have occupied an important place in the schools and universities.
A Russian chemist whose name is mentioned in histories of chemistry is Klaus, the discoverer of ruthenium. Klaus was a professor at the University of Kazan founded in 1804. Among his students and contemporaries were Nicholas Zinin (1812-80) and Alexander Butlerow (1828-86). Both these men occupied chairs first at Kazan and then St. Petersburg. Another student and professor at Kazan was Wladimir Markownikoff (18381904), who in 1873 was given the chair of chemistry in the University of Moscow. Other leaders in Russian chemistry at this time were Friedrich Beilstein (1838-1906), Nicolas Menschutkin (18421907) and the great Mendeléeff, who was born at Tobolsk in 1834, being the youngest of the fourteen children of the director of the Tobolsk College. Mendeléeff's grandfather had produced the first Siberian newspaper.

Appreciations of these distinguished chemists are to be found either in the columns of NATURE or the Journal of the Chemical Society. Several of them made important investigations concerning the petroleum of the Caucasus, but it is worth recalling that it was the Swedish engineer Ludwig Nobel (1831-88), elder brother of Alfred Nobel, who revolutionized the Baku oil industry and introduced pipe lines, tank cars and tank steamers, making a fortune where others had failed.

The most famous scientific man connected with the University of Kazan was Nicolai Lobatschewski (1793-1856). "What Vesalius was to Galen, what Copernicus was to Ptolemy, that was Lobatschewski to Euclid", wrote Clifford. Kazan owed much to his organizing powers, and forty years after his death his bust was placed in the University and a prize founded in his honour. In human interest even Lobatschewski is surpassed by the remarkable woman mathematician, Sophie Kowalevski (1850-91). Her romantic marriage to Woldemar Kowalevski (1843-83), professor of palæontology at Moscow; his tragic death and her subsequent rise to fame make a story as interesting as one of her own novels. Her reputation was such that in 1886 , when she was holding the chair of higher mathematics at Stockholm, the Paris Academy of Sciences broke through all the traditions of two centuries by admitting her to one of its meetings. As she entered, the whole of the members rose to salute her and the president declared that her presence should be a cause of pleasure not only to the mathematicians present but also to the whole company.

If space permitted, something might be said about the rise of engineering in Russia. One of Smeaton's last atmospheric engines was fitted up at Kronstadt, and both Smeaton and Watt were invited to Russia in the days of Catherine II. The first engineering shops in St. Petersburg were 
set up by British engineers, among whom were the Bairds, Handyside and the younger Matthew Murray. The early history of the engineering and other industries in Russia, however, is receiving the attention of Prof. P. P. Zabarinskij and other members of the Institute for the History of Science and Technics of the Academy of Sciences of the U.S.S.R., and already many interesting documents and facts have been brought to light and published.

\title{
PRESENT-DAY SCIENCE AND TECHNOLOGY IN THE U.S.S.R.
}

\author{
By Pruf. J. D. Bernal, F.R.S.
}

GCIENCE is a collective human enterprise. S It belongs to no country or race. Yet at different periods it has owed its chief advance to the activities of men first in one part of the worla and then in another. Modern seience originated in Italy in the sixteenth century, spread to the Low Countries, and thence to England and France. It was in England that it first achieved effective organization in the Royal Society. The nineteenth century saw it established in every industrial country of the world, notably in Germary and the United States. In each of these countries a characteristic contribution was made both to the extent of new knowledge and to the new means of gaining it. In this century, the contribution that the new Union of Sncialist Soviet Republics has made to science is as significant as any of the major contributions of other origins in the past.

Science, of course, was not a new thing in Russia. It can date its introduction as a living force to the many-sided genius of Lomonosof in the eighteenth century; and Russians can well be proud of the achievements of such men as Mendeléeff and Pavlov. But all these were relatively isolated workers. In no sense could the state of science in Russia before the Revolution be compared with that of Germany or Great Britain. The great change which the revolution brought about was to make conscious for the first time the necessary connexion between the ordered development of science and the life and work of the whole community. In this, of course, the new Government was inspired by the ideas of Marx and Engels, who had taken a lifelong interest in the progress and importance of science. Lenin had a wider and deeper knowledge of science than any statesman of his day, and even in the most difficult period of famine and civil war he laid the foundations of an entirely new development of science.

The conscious utilization of science, though to a certain extent implicit in State scientific institutions such as the Kaiser Wilhelm Gesellschaft in Germany and the Department of Scientific and
Industrial Research in Great Britain, was foreign to the Western democracies; and this has made it difficult for many scientific workers to understand and appreciate the achievements of Soviet science. The task that was undertaken was not to push forward the bounds of knowledge by the work of a few isolated specialists, but to make scientific the whole productive and cultural activity of $\mathbf{1 6 0}$ million people, only a tiny minority of whom had any previous acquaintance with science or technology. The first twenty years of the Republic's life was occupied in a double task : the building up of scientific education, and the application of science to industrial, agricultural and medical needs. It was first necessary to create a body of competent scientific workers, starting from the handful that had sufficed for the needs of the Tzarist State. In 1919 there were only forty trained physicists in the whole of the Union. New schools, new universities, new scientific research institutes had to be founded and manned, and the necessary scientific instruments manufactured for them. Meanwhile, immediate problems of electrification, communications and agriculture had to.be solved. This gigantic task could only have been achieved because it had behind it the enthusiastic interest and support of the whole people. It is characteristic of times of rapid progress and reconstruction that interest in knowledge should reach new heights. It was so at the dawn of the Greek City State, in the Italian Renaissance, in Civil War England; and it was certainly so not only for the Russians, but also for the submerged subject races of the old Empire-Mongols, Kazaks, Turkmen, Tartars, Georgians and Armenians.

In the creation of a new world it would be idle to look for the quietly pursued excellence and sound and acute scholarship that characterize an oldestablished and stable society. Science in the Soviet Union is not like science in Denmark or Switzerland. Nevertheless, the contribution to the advancement of knowledge made by the Soviet Union has been marked and important. In certain fields, especially in technology, Soviet discoveries 